\title{
PENGARUH PERILAKU KONSUMEN, BRAND IMAGE DAN PROMOSI TERHADAP KEPUTUSAN PEMBELIAN ONLINE PADA SITUS BELANJA ONLINE (Studi Kasus pada Situs Belanja Online XYZ)
}

\author{
Adhi Bawono1, Isanawikrama², Kusumah Arif ${ }^{3}$, Yohanes Jhony Kurniawan ${ }^{4 *}$ \\ ${ }^{1}$ Binus Entrepreneurship Center, Binus University \\ 2Binus Entrepreneurship Center, Binus University \\ ${ }^{3}$ Binus Entrepreneurship Center, Binus University \\ ${ }^{4}$ Sekolah Tinggi Ilmu komunikasi dan Sekretari Tarakanita
}

\begin{abstract}
E-Commerce is electronic commerce related to the activity of buying, selling, marketing of goods or services by utilizing internet communication network as a form of future trading.. The purpose of this research is (1) To know the influence of consumer behavior toward online purchasing decision on E Commerce Site, (2) to know the influence of brand image to online purchasing decision on E Commerce Site, (3) to know the influence of promotion to online purchasing decision at E-Commerce Sites XYZ. The method used in this study is a quantitative research method and use if the data SPSS Version 24.00. Populations and samples (questionnaires) in this study were 97 valid questionnaires. Questionnaire materials include: Functional Image (image seen from product function), Affective Image (image seen from attitudes toward brand), and Reputation (image seen from reputation of brand) disseminated to E Commerce Site XYZ user in Jakarta. this is: Based on the results of research and discussion, it can be concluded as follows: (1) Partially, the dimensions of Consumer Behavior have a significant and positive effect on Purchase Decision at E-Commerce Sites XYZ received with a significance value of 0.618, (2) Partially, image has a significant and positive effect on Purchasing Decision at E Commerce Site XYZ received with a significance value of 0.323, (3) Partially, the promotion dimension has a significant and positive effect on Purchase Decision at E Commerce Sites received with a significance value of 0.765 .
\end{abstract}

Keywords: Consumer Behaviour, Brand Image, Promotion and Online Purchasing Decision.

\begin{abstract}
ABSTRAK
E-Commerce adalah perdagangan elektronik yang berkaitan dengan aktivitas pembelian, penjualan, pemasaran barang ataupun jasa dengan memanfaatkan jaringan komunikasi internet sebagai bentuk perdagangan masa depan.. Tujuan dalam penelitian ini adalah untuk mengetahui pengaruh Perilaku Konsumen Terhadap Keputusan Pembelian online pada situs belanja online XYZ. Metode yang digunakan dalam penelitian ini adalah metode penelitian kuantitatif dan menggunakan olah data SPSS Versi 24.00. Populasi dan sampel (kuisioner) dalam penelitian ini sebanyak 97 kuisioner yang valid. Materi kuisioner meliputi : Functional Image (citra dilihat dari fungsi produk), Affective Image (citra dilihat dari sikap terhadap merek), dan Reputation (citra dilihat dari reputasi merek) yang disebarkan kepada pegguna situs belanja online di Jakarta. Berdasarkan hasil penelitian dan pembahasan, dapat disimpulkan sebagai berikut: (1) Secara parsial, dimensi Perilaku Konsumen berpengaruh signifikan dan signifikan terhadap Keputusan Pembelian di situs belanja online XYZ yang diterima dengan nilai signifikansi 0,618, (2) Secara parsial, Citra berpengaruh positif dan signifikan terhadap Keputusan Pembelian di situs belanja online XYZ yang diterima dengan nilai signifikansi 0,323, (3) Secara parsial, dimensi promosi berpengaruh signifikan dan signifikan terhadap Keputusan Pembelian di situs belanja online XYZ yang diterima dengan nilai signifikansi 0,765
\end{abstract}

Kata Kunci: Perilaku Konsumen, Brand Image, Promosi dan Keputusan Pembelian Online

*email: dosnirohaku_9@yahoo.com 


\section{PENDAHULUAN}

\section{Latar Belakang}

Di era globalisasi saat ini dimana semuanya sudah serba canggih dan sudah masuk era digital.Perkembangan yang begitu signifikan terjadi bahkan dalam dunia pemsaran yang berbasis sitem online. Banyak perusahaanperusahaan besar yang sudah mempunyai nama bahkan perusahaan kecil dan usaha kelas menengah pun sudah banyak yang menggunakan online untuk memasarkan produknya.

Dalam perdagangan pun merupakan kegiatan yang dilakukan manusia sejak pertama kali adanya dan sejak awal dari peradabannya.Awalnya, proses perdagangan itu dilakukan secara konvensional atau melakukan tatap muka secara langsung dan pembayarannyapun dilakukan secara langsung. Memasuki era yang serba digital saat ini semuanya berubah.Dalam era yang serba teknologi inipun mulai melakukan pergeseran, perdaganganpun mulai melakukan pergeseran.Dari yang sifatnya langsung dan terbatas oleh ruang dan waktu, maka kini sudah tidak lagi.

Komunikasi pemasaran dalam beberapa tahun terakhir menjadi sebuah kebutuhan bagi perusahaan-perusahaan untuk mengembangkan segala produk yang akan diproduksi oleh perusahaan tersebut. Berkembangnya komunikasi pemasaran tidak terlepas dari perkembangan jaman pada saat ini. Pemasaran menurut AMA (The American Marketing Association) yang anggotanya terdiri atas sejumlah besar professional pemasaran di Amerika Serikat dan Kanada menyatakan demikian : "pemasaran ialah proses perencanaan dan pelaksanaan konsepsi, harga, promosi, distribusi ide, barang dan jasa untuk menciptakan pertukaran yang memuaskan individu serta tujuan organisasi”. Hal yang diungkap AMA memang berlaku di era seperti sekarang ini.(Jefkins, Frank. 1997).

Dalam dunia bisnis, penggunaan internet memang sangatlah penting adanya.Dengan berkembangnya teknologi informasi yang pesat menjadikan internet sebagai pertukaran informasi.Internet mempengaruhi bisnis, internet hadir dengan tantangan baru dan tantangan yang sudah ada bagi yang sudah menggunakannya.

Seperti kita ketahui bahwa dalam dunia peluang usaha dan bisnis, teknologi informasi dan komunikasi (TIK) digunakan untuk perdagangan secara elektronik atau dikenal dengan E-Commerce. E-Commerce adalah perdagangan elektronik yang berkaitan dengan aktivitas pembelian, penjualan, pemasaran barang ataupun jasa dengan memanfaatkan jaringan komunikasi internet sebagai bentuk perdagangan masa depan.

Hampir semua orang mengenal dengan kata online shopping (belanja secara online), yang saat ini muncul sebagai aplikasi popular dalam e-commerce. Aplikasi ini banyak digunakan dalam beberapa jenis bisnis dengan tujuan yang berbeda dan sebagai alat pertukaran informasi. Dengan menggunakan aplikasi online shopping transaksi pembelian menjadi lebih mudah tanpa harus bertatap muka dengan penjual karena dapat dilakukan tidak terbatas oleh jarak dan waktu. Salah satu situs internet di Indonesia yang menerapkan konsep $e$ commerce dan online shopping adalah situs $X Y Z$.

Kemudian menurut survei website $e$ commerce paling populer di Indonesia yang dilakukan oleh (Wijaya, Survei website ecommerce paling populer di Indonesia, 2014) diperoleh bahwa situs $X Y Z$ menempati urutan teratas atau pertama dari kategori website $e$ commerce paling populer, paling dikenal, persentase pengunjung, dan persentase pengunjung kembali.

Situs $X Y Z$ merupakan online retailer di Indonesia yang memberikan konsumernya kesempatan untuk membeli segala produk yang berkaitan dengan elektronik, dekorasi rumah tangga hingga produk kesehatan dan kecantikan. Produk pesanan akan diantar ke rumah dengan pelayanan kurir yang cepat dengan kualitas produk yang terbaru dan terbaik. Pembayaran juga dapat dilakukan dengan uang tunai bila tidak memiliki kartu kredit, namun anda akan dikenakan biaya sebesar Rp. 10.000 yang dibayarkan kepada agen pengeriman yang mengantar barang pesanan anda.

Perilaku konsumen (Consumer Behavior) yang menerangkan bahwa keputusan konsumen dalam pembelian selain dipengaruhi oleh karakteristik konsumen, dapat dipengaruhi oleh bauran pemasaran yang mencakup produk, harga, distribusi, dan promosi. Variabel-variabel tersebut di atas saling mempengaruhi proses keputusan pembelian sehingga menghasilkan keputusan pembelian yang didasarkan pada pilihan 
produk, pilihan merk, pilihan penyalur, waktu pembelian, jumlah pembelian (Kotler, 2005).

Perilaku konsumen akan menentukan proses pengambilan keputusan dalam pembelian mereka. Proses tersebut merupakan sebuah pendekatan penyelesaian masalah pada kegiatan manusia untuk membeli sebuah barang atau jasa dalam memenuhi keiginan dan kebutuhannya. Faktor-faktor yang mempengaruhi perilaku konsumen dalam keputusan pembelian akan dipengaruhi oleh faktor budaya, faktor sosial, faktor pribadi dan faktor psikologis (Kotler,Amstrong, 2006).

Menurut penelitian Kunto (2014) Image atau citra sebagai "seperangkat keyakinan, ide dan kesan yang dimiiliki seseorang terhadap suatu objek di mana sikap dan kesan yang dimiliki seseorang terhadap suatu objek sangat dikondisikan oleh citra objek tersebut". Hal ini berarti bahwa kepercayaan, ide serta impresi seseorang sangat besar ngaruhnya terhadap dan perilaku serta respon yang mungkin akan dilakukannya.

Menurut (Tjiptono, 2015:387) promosi merupakan bauran pemasaran yang berfokus pada upaya menginformasikan, membujuk dan mengingatkan kembali konsumen akan merek dan produk perusahaannya. Konsep pemasaran terintegrasi (Integrated Marketing Communication/IMC) dikembangkan sebagai pengembanganya, komunikasi ini lebih menekankan pada komunikasi dua arah yang menunjukan keselaran dan keterpaduan dalam hal tujuan, fokus, dan arah strategik antarelemen bauran pemasaran yaitu pada periklanan, promosi penjualan, personal selling, public relation, direct dan online marketing serta antar unsur bauran pemasaran yaitu produk, distribusi, harga dan komunikasi pemasaran. Keputusan perusahaan melakukan tindakan perbaikan pelayanan yang sistematis merupakan payung yang menentukan dalam menindaklanjuti komplain konsumen dari suatu kegagalan sehingga pada akhirnya mampu mengikat loyalitasi konsumen

Disamping itu berdasarkan keputusan pembelian yang kompleks, keputusan pembelian konsumen juga dipengaruhi oleh faktor individual, lingkungan, dan stimuli pemasaran yang pada akhirnya menimbulkan tanggapan konsumen pasca pembelian atas yang dikonsumsinya dan juga memberikan masukan bagi produsen atas respon konsumen tersebut relevansinya dengan strategi pemasaran (Assael, 2001). Oleh karena itu produsen dalam menawarkan produk hendaknya menekankan pada aspek kepuasaan konsumen, mengingat semakin beraneka ragamnya penawaran produk disatu sisi dan pada sisi lain konsumen menjadi selektif dalam memilih produsennya.

Menjaga hubungan baik antara konsumen dengan pelanggan ini ditunjukkan dengan keinginan konsumen untuk melakukan pembelian secara berulang terhadap produk bersangkutan, hal ini menunjukkan adanya kepercayaan dari konsumen terhadap produk tersebut. Keinginan konsumen untuk melakukan pembelian ulang ini dipengaruhi oleh beberapa faktor yaitu selain harga yang relatif murah, juga dipengaruhi oleh kualitas produk yang bagus dan ada kesesuian antara harga dengan kualitas yang didapat sehingga pada akhirnya timbul kepuasan pada konsumen selama menggunakan produk tersebut.

Terkait dengan hal tersebut maka sebuah perencanaan bisa sukses harus didasarkan pada suatu rerangka koseptual yang memberikan suatu dasar analisis, pelaksanaan, eksekusi dan evaluasi. Suatu pemahaman yang mendalam mengenai pemasaran dan perencanaan harus diusulkan dengan konsep dan ide kreatif yangbaik. Hal ini dilakukan agar dalam prakteknya, pemasaran yang dilakukan dapat menarik khalayak sebanyak mungkin

Dengan masih besarnya potensi pasar e-commerce di Indonesia, penulis melihat hal ini dapat dijadikan sebuah penelitian yang menarik dan dapat bermanfaat bagi semua kalangan terutama untuk kalangan enterpreanur dan pelaku usaha lainnya untuk ikut memanfaatkan perkembangan teknologi informasi dan komunikasi, dan memberikan gambaran bahwa masa depan dunia perdagangan adalah perdagangan online khususnya pada $X Y Z$

Berdasarkan hal-hal yang kemukakan di atas maka penelitian ini mengambil judul yaitu "Pengaruh Perilaku Konsumen, Brand Image dan Promosi terhadap Keputusan Pembelian Online pada Situs Belanja Online XYZ tahun 2017'.

\section{Rumusan Masalah Penelitian}

Berdasarkan latar belakang masalah tersebut, rumusan masalah dalam penelitian iniyaitu:1) 
bagaimanakah pengaruh perilaku konsumen terhadap keputusan pembelian online pada situs XYZ?, (2) Pengaruh brand image terhadap keputusan pembelian online pada situs XYZ tahun 2017, (3) Pengaruh promosi terhadap keputusan pembelian online pada situs $X Y Z$ tahun 2017 ?

\section{Tujuan Penelitian}

Tujuan yang ingin dicapai dalam penelitian ini adalah (1) Untuk mengetahui Pengaruh Perilaku Konsumen terhadap Keputusan Pembelian online pada Situs Belanja Online XYZ, (2) Untuk mengetahui Pengaruh brand image terhadap Keputusan Pembelian online pada situs belanja Online $X Y Z$, (3) Untuk mengetahui pengaruh promosi terhadap keputusan pembelian online pada situs belanja online XYZ.

\section{KAJIAN TEORI}

\section{Definisi Perilaku Konsumen (Consumer Behavior)}

Pengertian consumer behavior adalah studi dari individu, kelompok, atau organisasi dan proses yang mereka gunakan untuk memilih, mengamankan, menggunakan, menempatkan produk, pelayanan, pengalaman, atau ide untuk memuaskan kemauan dan dampak dari proses ini kepada konsumen dan masyarakat (Hawkins et al., 2007:6).

Ruang lingkup consumer behavior mencakup banyak hal karena consumer behavior adalah sebuah studi dari proses yang berkembang ketika individu atau sekelompok orang memilih, menggunakan, atau membuang sebuah produk, pelayanan, ide, atau pengalaman untuk memuaskan kebutuhan dan keinginan (Solomon, 2007:7).

Sehingga consumer behavior bisa disimpulkan sebagai studi mengenai pribadi seseorang atau kelompok dalam menentukan hak mereka dalam memilih, membeli, menggunakan, dan mengganti suatu produk atau layanan agar tercapainya apa yang mereka inginkan dari suatu produk atau layanan tersebut.

Sedangkan menurut Kotler (2007) bahwa, "perilaku konsumen merupakan studi tentang cara individu, kelompok, dan organisasi menyeleksi, membeli, menggunakan, dan memposisikan barang, jasa, gagasan, atau pengalaman untuk memuaskan kebutuhan dan keinginan mereka"
Faktor-faktor yang Mempengaruhi Perilaku Konsumen(Consumer Behavior)

Menurut Kotler dan Amstrong (2012: 135150), faktor-faktor yangmempengaruhi Perilaku Konsumen (Consumer Behavior) adalah:

a) Budaya, sub-budaya dan kelas sosial sangat penting bagi perilaku pembelian. Budaya merupakan kumpulan dari nilai dasar, persepsi, keinginan, dan perilaku yang dipelajari dari anggota sosial seperti keluargadan institusi penting lainnya. Sub-budaya adalah sekelompok orang yangberbagi nilai sistem berdasarkan pengalaman hidup dan situasi (nasionalisme, agama, dan ras). Kelas sosial relatif permanen dimana anggotanya berbagi nilai, ketertarikan, dan perilaku yang mirip.

b) Sosial, perilaku konsumen dipengaruhi oleh faktor-faktor sosial seperti kelompok acuan, keluarga, serta peran dan status sosial.

c) Pribadi, keputusan pembelian juga dipengaruhi oleh karakteristik pribadi, meliputi usia, tahap dalam siklus kehidupan, pekerjaan, dan keadaan ekonomi.

d) Psikologis, satu perangkat proses psikologis berkombinasi dengan karakteristik konsumen tertentu untuk menghasilkan proses keputusan dan keputusan konsumen.

\section{Tipe Perilaku Pembelian Konsumen (Consumer Behavior)}

Menurut Kotler \& Amstrong (2012:150152), tipe-tipe perilaku pembelian berdasarkan tingkat keterlibatan pembeli dan tingkat perbedaan diantara berbagai merek adalah sebagai berikut:

a) Perilaku Pembelian Kompleks (Complex Buying Behavior)

Konsumen melakukan pembelian kompleks ketika mereka sangat terlibat dalam pembelian dan merasakan perbedaan yang signifikan antara merek. Konsumen mungkin sangat terlibat bila produk mahal, beresiko, jarang dibeli, dan sangat menonjolkan ekspresi diri. Konsumen biasanya banyak mempelajari mengenai kategori produk.

b) Perilaku pembelian mengurangi ketidakcocokan (Dissonance-Reducing Buying Behavior) 
konsumen melakukan pembelian yang mengurangi ketidakcocokan terjadi ketika konsumen sangat terlibat dalam pembelian yang mahal, beresiko, tetapi hanya melihat sedikit perbedaan antara merek.

c) Perilaku pembelian karena kebiasaan (Habitual-Buying Behavior). Perilaku pembelian karena kebiasaan terjadi dibawah kondisi keterlibatan konsumen yang rendah dan melihat sedikit perbedaan antara merek yang signifikan.Tidak memiliki komitmen yang kuat dengan merek apapun.

d) Perilaku pembelian mencari variasi (Variety-Seeking Buying Behavior). Perilaku pembelian yang mencari variasi terjadi ketika tingkat keterlibatan konsumen rendah tetapi perbedaan merek yang dirasakan signifikan.Dalam hal ini, konsumen sering berganti merek. Contohnya seperti membeli kue, konsumen mungkin memegang beberapa keyakinan, memilih kue tanpa banyak evaluasi, kemudian mengevaluasi kue tersebut ketika dikonsumsi.Tetapi lain kali, konsumen akan mengganti dengan merek lain karena bosan atau hanya ingin mencoba sesuatu yang berbeda

\section{Brand image \\ Pengertian Brand Image}

Citra merek merupakan serangkaian asosiasi(persepsi) yang ada dalam benak konsumen terhadap suatu merek, biasanya terorganisasi menjadi suatu makna. Hubungan terhadap suatu merek akan semakin kuat jika didasarkan pada pengalaman dan mendapat banyak informasi. Citra atau asosiasi merepresentasikan persepsi yang bisa merefleksikan kenyataan yang objektif ataupun tidak.

Menurut (Kotler 2012), " A brand is name, term, sign, symbol, or design, or acombination of them, intended to identify the goods or service of one seller or group of sellers and to differentiate them from those of competitor." Maksudnya, merek adalah nama, istilah, tanda, simbol, desain atau kombinasi dari semuanya itu yang dimaksudkan untuk mengidentifikasi barang atau jasa dari seseorang atau sekelompok penjual untuk membedakannya dari produk atau barang pesaing.

Brand Image adalah representasi dari keseluruhan persepsi terhadap merek dan dibentuk dari informasi dan pengalaman masa lalu terhadap merek itu. Citra terhadap merek berhubungan dengan sikap yang berupa keyakinan dan preferensi terhadap suatu merek. Konsumen yang memiliki citra yang positif terhadap suatu merek, akan lebih memungkinkan untuk melakukan pembelian (Setiadi, 2003).

Dari beberapa pendapat para ahli diatasdapat disimpulkan bahwa citra merek adalah persepsi konsumen dan preferensi terhadap merek, sebagaimana yang direfleksikan oleh berbagai macam asosiasi (presepsi)merek yang ada dalam ingatan konsumen.

\section{Faktor yang Mempengaruhi Citra Merek}

Aker 2007: 139) berpendapat citra merek terdiridari tiga komponenyaitu:

1. Product Attributes (Atribut Produk) : hal-hal yang berkaitan dengan merek tersebut sendiri seperti, kemasan, isi produk, harga, rasa, dll.

2. Consumer Benefits (Keuntungan Konsumen): kegunaan produk dari merek tersebut.

3. Brand Personality (Kepribadian Merek) : merupakan asosiasi (presepsi) yang membayangkan mengenai kepribadian sebuah merek apabila merek tersebut seorang manusia.

\section{Dimensi Brand Image}

Dalam penelitian ini, penulis menggunakan tiga dimensi brand image (dalam jurnal Mahsa Hariri dan Hossein Vazifehdust, 2011) yang terdiri dari functional image (citra dilihat dari fungsi produk), affective image (citra dilihat dari sikap terhadap merek), dan reputation (citra dilihat dari reputasi merek).

\section{Promosi \\ Pengertian Promosi}

Promosi merupakan salah satu faktor penentu keberhasilan program pemasaran. Bagaimanapun kualitas suatu produk apabila konsumen tidak tahu dan tidak yakin bahwa produk tersebut memiliki kualitas dan berguna bagi mereka, maka konsumen pun tidak akan tertarik untuk membelinya. Menurut (Tjiptono, 2015:387), promosi merupakan bauran pemsaran yang berfokus pada upaya menginformasikan, membujuk dan mengingatkan kembali konsumen akan merek dan produk perusahaannya. 
Konsep pemasaran terintegrasi (Integrated Marketing Communication/IMC) dikembangkan sebagai pengembanganya, komunikasi ini lebih menekankan pada komunikasi dua arah yang menunjukan keselaran dan keterpaduan dalam hal tujuan, fokus, dan arah strategik antar elemen bauran pemasaran yaitu pada periklanan, promosi penjualan, personal selling, public relation, direct dan online marketing serta antar unsur bauran pemasaran yaitu produk, distribusi, hargadan komunikasi pemasaran.

Tujuan akhir dari pemasar adalah menaikan penjualan dan keuntungan bagi perusahaan.Promosi dan periklanan adalah usaha-usaha perusahaan untuk meyakinkan konsumen untuk membeli produknya.

Bentuk-bentuk utama dari komunikasi penjualan adalah penjualan pribadi (personal selling), periklanan (advertaising), promosi penjualan (sales promotion), iklan dari mulut ke mulut (mouth to mouth advertisement)

\section{Macam macam promosi}

Menurut Kotler(2015:399), macam-macam bauran promosi penjualan terdiridarisales promotion, advertising, personal selling, dan public relations.

Berikut ini mnerupakan pembahasan darimacam-macam bauran promosi penjualanadalah sebagai berikut.

\section{Promosi Penjualan (Sales Promotion)}

Menurut Kotler (2006), sales promotion is a short- term incentives to encourage the purchase or sale of a product or service. Pengertiannya adalah, promosi merupakan insentif jangka pendek untuk mendorong pembelian/penjualan suatu produk atau jasa.

\section{Periklanan (Advertising)}

Menurut Kotler (2006), advertising is a any paid form of nonpersonal presentation and promotion of ideas, goods, or services by an identified sponsor. Pengertiannya adalah, iklan adalah sebagai semua bentuk bayaran untuk mempresentasikam dan mempromosikan ide, barang, atau jasa secaranon personal oleh sponsor yang jelas.

\section{Personal Selling}

Menurut Tjiptono (2015), personal selling adalah komunikasi langsung (tatap muka) antara penjual dan calon pelanggan untuk memperkenalkan suatu produk kepada calon pelanggan dan membentuk pemahaman pelanggan terhadap produk sehingga mereka kemudian akan mencoba membelinya.

\section{Hubungan Masyarakat (Public relation)}

Sedangkan menurut Tjiptono (2008), public relations merupakan upaya komunikasi menyeluruh dari suatu perusahaan untuk mempengaruhi persepsi, opini, keyakinan, dan sikap terhadap berbagai macam kelompok terhadap perusahaan tersebut

\section{Indikator promosi}

Promosi adalah pemilihan bauran promosi yang sangat penting untuk dilaksanakan oleh perusahaan untuk memasarkan jasa dalam kegiatan pembelian / penggunaan jasa.

Metode tersebut terdiri atas aktivitas periklanan (advertising), personal selling, promosi penjualan, public relations, informasi dari mulut kemulut (word of mouth), dan pemasaran langsung (direct marketing). (Kotler, 2009:24) Walaupun secara umum bentuk-bentuk promosi memiliki fungsi yang sama, tapi bentukbentuk tersebut dapat dibedakan berdasarkan tugas-tugas khususnya.

\section{Definisi Keputusan Pembelian}

Kotler, (2011:206), mengungkapkan keputusan untuk membeli yang diambil oleh konsumen itu merupakan kumpulan dari sejumlah keputusan.

Setiap keputusan membeli mempunyai suatu struktur yang terdiri dari beberapa komponen, antara lain. 1) Keputusan tentang jenis produk, 2) Keputusan tentang bentuk produk, 3) Keputusan tentang merek, merek mana yang akan dipilih konsumen untuk dibeli, 4) Keputusan tentang penjualnya, produk tersebut dibeli dimana dan pada toko apa, 5) Keputusan tentang jumlah produk, banyaknya produk yang akan dibeli, 6) Keputusan tentang waktu pembelian. 7) Keputusan tentang cara pembayaran.

\section{Faktor faktor yang Memengaruhi Keputusan Pembelian}

Selanjutnya menurut Kotler, (2011:206) mengungkapkan bahwa terdapat dua faktor yang pada akhirnya mempengaruhi keputusan pembelian, pertama, sikap orang lain. Sejauh mana sikap orang lain mengurangi alternatif yang disukai seseorang, pengurangan 
alternatif tersebut akan bergantung kepada dua hal yaitu; 1) Intensitas sikap negatif orang lain terhadap alternatif yang disukai konsumen. 2) Motivasi konsumen untuk menuruti keinginan orang lain.

Kedua, Situasi yang tidak terantisipasi.Situasi yang tidak terantisipasi yang dapat muncul dan mengubah niat pembelian, keputusan konsumen untuk memodifikasi, menunda atau menghindari suatu keputusan pembelian sangat dipengaruhi oleh resiko yang dirasakan.

Bersama resiko yang dirasakan berbeda-beda menurut besarnya uang yang dipertaruhkan besarnya ketidakpastian atribut dan besarnya kepercayaan diri konsumen.

Keputusan membeli melalui secara online yang didahului oleh pengenalan kebutuhan, pencarian informasi, evaluasi alternatif dipengaruhi oleh banyak faktor.

Faktor ini dapat dikelompokkan menjadi faktor internal, yaitu psikologi konsumen, dan faktor eksternal, yang terdiri dari lingkungan sosial budaya masyarakat, stimuli pemasaran, dan sistem kontrol vendor yang meliputi (1) Efisiensi untuk pencarian (waktu cepat, mudah dalam penggunaan, dan usaha pencarian mudah); (2) Value (harga bersaing dan kualitas baik); dan (3) interaksi (informasi, keamanan, load time, dan navigasi (Suhari, Yohanes. 2008).

\section{Dimensi Keputusan Pembelian}

Ada beberapa dimensi atau tahap yang dilakukan oleh konsumen dalam proses pembelian (Kotler \& Keller. 2009 : 234-245), yaitu:

a) Pengenalan Masalah (Need Recognition, yaitu: proses pembelian dimulai dengan pengenalan terhadap masalah atau kebutuhan. Konsumen merasakan adanya perbedaan antara keadaan sebenarnya dengan keadaan yang diinginkan.Dipicu oleh rangsangan internal yaitu ketika salah satu kebutuhan normal yang timbul sudah cukup tinggi sehingga menciptakan sebuah dorongan. Dan rangsangan eksternal yaitu karena dorongan dari pihak lain yang membuat konsumen menjadi terdorong untuk memenuhi kebutuhannya

b) Pencarian Informasi (Search of Information),yaitu: konsumen dapat memperoleh informasi dari berbagai sumber, meliputi :
1) Sumber pribadi meliputi keluarga, teman, tetangga.

2) Sumber komersil meliputi iklan, tenaga penjual, pameran.

3) Sumber publik meliputi media massa, organisasi konsumen, pencarian minternet.

4) Sumber pengalaman meliputi penanganan, pemeriksaan, penggunaanproduk.

c) Evaluasi Alternatif

(Alternative

Evaluation), yaitu: evaluasi alternatif yaitu cara konsumen dalam memproses informasi untukmengevaluasi merek alternatif yang menghasilkan pilihan berbagai merek.

d) Keputusan Pembelian (Purchase Decision) adalah tahap dimana konsumen akan membeli atau tidak. Ada dua faktor yang muncul diantara kecenderungan pembelian dan keputusan pembelian. Faktor pertama adalah sikap orang lain dan faktor kedua adalah situasi tidak terduga. Konsumen mungkin membentuk kecenderungan pada pendapat yang diharapkan, harga, dan manfaat produk yang diharapkan.

e) Perilaku Setelah Pembelian (Postpurchase Behavior). Setelah pembelian terjadi, konsumen akan mengalami suatu tingkat kepuasanatau ketidakpuasan. Kepuasan atau ketidakpuasan akan mempengaruhitingkah laku berikutnya. Konsumen yang merasa puas akan cenderung mengatakan hal yang baik tentang produk yang bersangkutan kepada oranglain.

Apabila konsumen merasa tidak puas maka ada dua kemungkinan yangakan dilakukan oleh konsumen.Pertama, meninggalkan atau konsumen tidakakan melakukan pembelian yang kedua kalinya. Kedua, konsumen akanmencari informasi tambahan mengenai produk yang telah dibelinya untuk menguatkan pendiriannya mengapa ia memilih produk itu sehingga ketidakpuasannya dapat dikurangi

\section{Hipotesis}

Hipotesis adalah suatu jawaban yang bersifat sementara terhadap permasalahan penelitian, sampai terbukti melalui data yang terkumpul. (Suharsimi, 2010:71).

Dari uraian kerangka pemikiran diatas, dirumuskan sebagai berikut: 
$\mathrm{H}_{1} \quad=$ di duga terdapat Pengaruh Perilaku Konsumen terhadap Keputusan Pembelian online pada Situs Belanja Online $X Y Z$ tahun 2017

$\mathrm{H}_{2} \quad=$ di duga terdapat Pengaruh brand image terhadap Keputusan Pembelian online pada Situs Belanja Online $X Y Z$ tahun 2017

$\mathrm{H}_{3} \quad=$ di duga terdapat Pengaruh promosi terhadap Keputusan Pembelian online pada Situs Belanja online XYZ tahun 2017

\section{Kerangka Pemikiran}

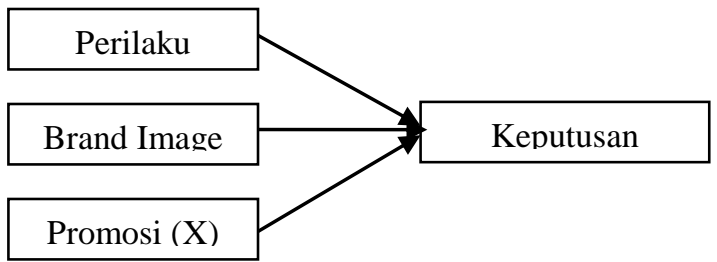

Gambar 1. Kerangka pemikiran

\section{METODE PENELITIAN \\ Waktu dan Tempat Penelitian \\ Waktu penelitian}

Proses penelitian ini diawali dengan kegiatan mengidentifikasi permasalahan di tempat yang akan di gunakan sebagai lokasi penelitian, perumusan masalah yang teridentifikasi, pengumpulan dasar teori yang memperkuat landasan dalam variable, penyusunan metode dalam pengumpulan data, hingga penentuan teknik pengujian statistic yang di pergunakan. Pada proses ini dibutuhkan waktu penelitian sejak Agustus -September 2017

\section{Tempat penelitian}

Untuk memperoleh data guna penyusunan karya tulis penulis mengambil tempat penelitian pada pengguna situs belanja online XYZ di Jakarta

\section{Desain Riset}

Menurut Arikunto (2010:90), desain penelitian adalah rencana atau rancangan yang dibuat oleh peneliti, sebagai ancar-ancar kegiatan yang akan dilaksanakan. Penelitian ini menggunakan pendekatan kuantitatif, berjenis deskriptif dan asosiatif. Dikatakan pendekatan kuantitatif sebab pendekatan yang digunakan di dalam usulan penelitian, proses, hipotesis, turun ke lapangan, analisa data dan kesimpulan data sampai dengan penulisannya menggunakan aspek pengukuran, perhitungan, rumus dan kepastian data numerik. Penelitian ini merupakan penelitian deskriptif karena bertujuan membuat pencanderaan/ lukisan/ deskripsi mengenai fakta-fakta dan sifat -sifat suatu populasi atau daerah tertentu secara sistematik, faktual dan teliti (Ginting dan Situmorang, 2008:55).

Selanjutnya dikatakan sebagai penelitian asosiatif karena penelitian ini menghubungkan dua variabel atau lebih (Ginting, 2008:57). Dengan penelitian ini maka akan dapat dibangun suatu teori yang dapat berfungsi untuk menjelaskan, meramalkan dan mengontrol suatu gejala.

\section{Jenis dan Sumber Data Jenis Data}

Jenis data yang digunakan dalam penelitian ini adalah data kuantitatif yang merupakan data yang diperoleh dari dalam perusahaan baik lisan maupun tulisan yang kemudian dikuantitatifkan berupa angka-angka atau bilangan baik utuh (diskrit) maupun tidak utuh (continue) (Kountur, 2008:30) atau skor jawaban reponden yang diperoleh dari hasil pengukuran melalui koesioner. Penelitian ini menggunakan skala pengukuran berupa skala likert dengan 4 kategori.

Tabel 2 ukuran skala likert

\begin{tabular}{|c|c|}
\hline Jawaban & Skor \\
\hline Sangat Setuju & 4 \\
\hline Setuju & 3 \\
\hline Tidak Setuju & 2 \\
\hline Sangat Tidak Setuju & 1 \\
\hline
\end{tabular}

Sumber: Hasil kajian penulis, 2017

Skala pengukuran penelitian ini menggunakan empat kategori pilihan bertujuan untuk menghilangkan jawaban ragu-ragu dari reponden.Penelitian ini menggunakan kuesioner yang berupa pernyataan-pernyataan yang pilihan jawabannya telah tersedia.Yang diberi pola atau dipersempit dengan kerangka susunan terlebih dahulu, sehingga mendorong reponden untuk menentukan pilihan jawaban ke suatu arah dan memiliki keuntungan yang cepat dan mudah dianalisa.

\section{Sumber Data}


Sumber data bersumber dari data primer dan data sekunder Indriantoro dan Supomo (2002:146-147), yaitu :

1. Data Primer (Primary Data) merupakan sumber data penelitian yang diperoleh secara langsung dari sumber langsung (tidak melalui media perantara). Data primer secara khusus dikumpulkan peneliti untuk menjawab pertanyaan penelitian. Data primer dapat berupa opini, hasil observasi dan hasil pengujian. Metode yang digunakan untuk mendapatkan data primer adalah dengan wawancara atau jawaban kuisioner.

2. Data sekunder (Secondary Data) merupakan sumber data penelitian yang diperoleh peneliti secara tidak langsung melalui media perantara (dari pihak lain). Data sekunder umumnya berupa bukti, catatan, atau laporan historis yang telah tersusun dalam arsip yang dipublikasikan maupun tidak dipublikasikan.

\section{Metoda Analisis Data}

Penelitian ini menggunakan uji validitas dan reliabilitas sebelum melakukan uji hipotesis. Uji validitas dan reliabilitas bertujuan untuk mengetahui ketepatan dan keandalan data sehingga data tersebut memenuhi kriteria untuk diuji dengan menggunakan berbagai jenis metode statistik yang ada.

\section{Populasi dan Sample Populasi.}

Pengertian populasi menurut Sugiyono (2012:90) adalah wilayah generalisasi yang terdiri atas obyek/subyek yang mempunyai kualitas dan karakteristik tertentu yang ditetapkan oleh peneliti untuk dipelajari dan kemudian ditarik kesimpulannya. Populasi yang diteliti adalah seluruh konsumen prioritas bulan April 2017 pada situs belanja online $X Y Z$ yaitu sebanyak 3186 konsumen.

\section{Sample}

Teknik sampling yang digunakan dalam pengambilan sampel dalam penelitian ini adalah simple random sampling yaitu menurut Sugiyono (2012:118) adalah teknik pengambilan anggota sampel dari populasi yang dilakukan secara acak tanpa memperhatikan strata yang ada dalam populasi itu. Dalam pengembilan sampel pada penelitian ini mengacu pada teori Slovin.

Banyaknya sample di situs belanja online XYZ pada bulan agustus sampai
September 2017 sebanyak 3186 konsumen. Dari jumlah tersebut yang dijadikan sampel dalam penelitian ini adalah sebanyak 3186 konsumen. Penentuan jumlah sampel sebanyak 186 konsumen untuk memudahkan dalam pengolahan data konsumen dan diperoleh berdasarkan rumus Slovin (Arikunto :2006:102) sebagai berikut:

Perhitungan sampel dilakukan dengan menggunakan rumus Slovin dengan asumsi bahwa populasi tersebut berdistribusi normal, maka perhitungannya adalah sebagai berikut: (Umar, 2011).

$$
\begin{aligned}
N= & \frac{N}{1+N e^{2}} \\
& \text { Dimana : } \\
& \mathrm{n}=\text { Ukuran Sampel } \\
& \mathrm{N}=\text { Ukuran Populasi } \\
& \mathrm{e}=\text { Batas kesalahan yang } \\
& \text { diperbolehkan, sebanyak 10\% }
\end{aligned}
$$

Berdasarkan rumus tersebut, maka jumlah sampel yang diambil dalam penelitian ini adalah:

$$
\begin{aligned}
& N=\frac{3186}{1+3186(0,1)^{2}} \\
& N=\frac{3186}{32.86} \\
& \mathrm{~N}=96.95
\end{aligned}
$$

Dengan demikian, jumlah sampel dalam penelitian ini sebanyak 96.95 di bulatkan menjadi 97 sampel.

\section{HASIL DAN PEMBAHASAN}

\section{Hasil Analisis Deskriptif}

Di dalam penelitian ini, penulis menyebar kuesioner kepada konsumen situs belanja online $X Y Z$ melalui internet. Kuesioner yang disebarkan pada seluruh konsumen yang berjumlah 97 responden mengenai tanggapan tentang perilaku konsumen terhadap keputusan pembelian situs XYZ. .Untuk mendapatkan gambaran mengenai karakteristik responden berdasarkan jenis kelamin, usia. Untuk lebih jelasnya dibawah ini dikemukakan secara satu persatu gambaran umum responden penelitian.

\section{Karakteristik Responden Berdasarkan Jenis Kelamin}

Berdasarkan jenis kelamin peneliti membagi 2 (dua) kategori, yaitu laki-laki dan perempuan. Dengan melihat Tabel 1 dibawah ini dapat dilihat responden laki-laki dan perempuan. 
Tabel 1. Jenis Kelamin

Jenis Kelamin

\begin{tabular}{|c|c|c|c|c|c|}
\hline & & Frequency & Percent & Valid Percent & $\begin{array}{c}\text { Cumulative } \\
\text { Percent }\end{array}$ \\
\hline Valid & $\begin{array}{l}\text { laki laki } \\
\text { perempuan } \\
\text { Total }\end{array}$ & $\begin{array}{l}41 \\
56 \\
97\end{array}$ & $\begin{array}{r}42,3 \\
57,7 \\
100,0\end{array}$ & $\begin{array}{r}42,3 \\
57,7 \\
100,0 \\
\end{array}$ & $\begin{array}{r}42,3 \\
100,0\end{array}$ \\
\hline
\end{tabular}

Berdasarkan Tabel 1 dapat diketahui bahwa jenis kelamin dari total 97 responden yang berjenis kelamin laki-laki sebanyak 41 orang $(42,3 \%)$ dan sisanya perempuan 56 orang $(57,7 \%)$. Dengan ini diketahui sebagian besar responden yang jenis kelamin Konsumen situs $X Y Z$ bermayoritas berjenis kelamin perempuan.

\section{Karakteristik Responden Berdasarkan Usia \\ Berdasarkan usia responden peneliti membagi menjadi 4 kategori, yaitu < 20 tahun, 20 - 25 tahun, 25> tahun.Dengan melihat Tabel 2 dibawah ini dapat dilihat presentase usia responden.}

Tabel 2.Usia Responden

\begin{tabular}{|ll|l|l|l|l|}
\hline \multicolumn{1}{|c|}{} & & & & \\
& & Frequency & Percent & Valid Percent & $\begin{array}{l}\text { Cumulative } \\
\text { Percent }\end{array}$ \\
\hline Valid & $<20$ tahun & 29 & 29,9 & 29,9 & 29,9 \\
& $20-25$ tahun & 59 & 60,8 & 60,8 & 90,7 \\
& >25 tahun & 9 & 9,3 & 9,3 & 100,0 \\
& Total & 97 & 100,0 & 100,0 & \\
\hline
\end{tabular}

Berdasarkan Tabel 2 dapat diketahui bahwa usia dari total 97 responden pada sebanyak 29orang (29.9\%) yang berusia $<20$ tahun ,59orang $(60.8 \%)$ yang berusia 20 25 tahun, 9orang $(9,3 \%)$ yang berusia $>25$ tahun. Dengan ini diketahui usia responden yang bermayoritas berusia 20-25 tahun untuk konsumen situs $X Y Z$.

\section{Hasil Uji Teknik Analisa data Hasil Uji Validitas}

Uji validitas di gunakan mengetahui apakah item item yang ada di dalam kusioner mampu mengukur peubah yang di dapatkan dalam penelitian ini. (Ghozali 2011:69). Maksudnya untuk mengukur valid atau tidaknya suatu kuisioner di lihat jika pertanyaan dalam kuisioner tersebut mampu

mengungkapkan sesuatu yang akan di ukur oleh kuisioner tersebut.

Uji validitas ini dapat di lakukan dengan menggunakan korelasi antara skor butir pertanyaan dengan skor konstruk atau variable. Setelah itu tentukan hipotesis $\mathrm{H}_{\mathrm{o}}$ : skor butir pertanyaan positif dengan skor konstruk dan Ha: skor butir pertanyaan tidak berkorelasi positif dengan total skor kunstruk.

Setelah menentukan hipotesis Ho dan Ha kemudian uji dengan membandingkan $r$ hitung (tabel corrected item - total correlation) dengan $\mathrm{r}$ tabel (tabel product moment dengan signifikan 0.05)untuk degreee of fredom $(d f)=\mathrm{n}-2$ di mana " $\mathrm{n}$ " adalah jumlah smapel penelitian sebanyak 97 responden sehingga di peroleh nilai (df) 97-2 atau nilai df dari 95 adalah 0.196. Suatu kuisioner di yatakan valid apabila $r$ hitung $>r$ tabel (ghazali, 2011:69).

Pengujian validitas dalam penelitian ini menggunakan teknik korelasi pearson product moment dengan menggunakan program SPSS versi 24.0 for windows. Kriteria validitas setiap item atau butir pernyataan adalah apabila nilai korelasi tiap item tersebut bernilai positif dan besarnya 0,3 keatas, berarti item atau butir pernyataan tersebut valid (Sugiyono, 2013).

Hasil pengujian validitas terhadap variabel Perilaku konsumen (X1), brand image (X2), Promosi (X3) terhadap keputusan pembelian (Y) bahwa nilai korelasi dari masing-masing variabel lebih besar dari 0,196, sehingga tidak ada yang perlu dikeluarkan dan tidak perlu dilakukan pengujian ulang.

\section{Hasil Uji Reliabilitas}

Hasil perhitungan koefisien korelasi dan reliabilitas untuk setiap variabel penelitian 
dengan metode Cronbach's Alpha disajikan

pada tabel di bawah ini:

Tabel 3. Hasil Uji Realiabilitas

\begin{tabular}{|c|l|c|c|c|}
\hline \multicolumn{1}{|l|}{ No } & \multicolumn{1}{|c|}{ Variabel } & Cronbach's Alpha & r kritis & Keterangan \\
\hline 1 & Perilaku konsumen (X1) & 0,931 & 0,6 & Reliabel \\
\hline 2 & Brand image (X2) & 0,883 & 0,6 & Reliabel \\
\hline 3 & Promosi (X3) & 0,925 & 0,6 & Reliabel \\
\hline 4 & Keputusan pembelian (Y) & 0,810 & 0,6 & Reliabel \\
\hline
\end{tabular}

Dari data Table 3 menunjukkan bahwa nilai Cronbach's Alpha untuk masingmasing variabel diatas ketentuan nilai yang disyaratkan $(>0,6)$. Maka dikatakan bahwa konstruk pernyataan yang merupakan variabel Perilaku konsumen (X1), brand image (X2), promosi (X3) dan Keputusan pembeliankonsumen E Commerce Sites (Y)dinyatakan reliable

\section{Hasil Uji Asumsi Klasik \\ Uji Normalitas}

Uji normalitas bertujuan untuk mengetahui apakah masing-masing variabel berdistribusi normal atau tidak.uji normalitas data dalam penelitian ini adalah menggunakan uji Kolmogorov-Smirnov.Jika nilai sig > 0,05 maka data berdistribusi normal sebaliknya jika nilai sig $<0,05$ maka data tidak berdistribusi normal. Adapun hasil uji normalitas dalam penelitian ini adalah sebagai berikut :

Tabel 4 Hasil Uji Normalitas

One-Sample Kolmogorov-Smirnov Test

\begin{tabular}{|ll|r|}
\hline & & \multicolumn{2}{|c|}{$\begin{array}{c}\text { Unstandardized Predicted } \\
\text { Value }\end{array}$} \\
\hline $\mathrm{N}$ & & 97 \\
Normal Parametersa,b & Mean & 42,7319588 \\
& Std. Deviation & 2,89391864 \\
Most Extreme Differences & Absolute &, 105 \\
& Positive &, 073 \\
& Negative &,- 105 \\
Kolmogorov-Smirnov Z & & 1,037 \\
Asymp. Sig. (2-tailed) & &, 233 \\
\hline
\end{tabular}

a. Test distribution is Normal.

b. Calculated from data.

Berdasarkan Tabel 4 dapat dilihat bahwa nilai sig > 0,05 yaitu 0,233 sehingga dapat disimpulkan residual data berdistribusi normal dan model regresi telah memenuhi asumsi normalitas.

\section{Hasil uji hipotesis \\ Hasil Uji Koefisien Determinasi $\mathbf{R}^{2}$}

Koefisian Determinasi $\left(\mathrm{R}^{2}\right)$ pada intinya mengukur seberapa jauh kemampuan model dalam menerangkan variabel dependen. Nilai koefisian determinasi adalah

antara nol sampai dan satu.Nilai determinasi ditentukan dengan nilai Adjusted R Square.

Hasil pengujian koefisian determinasi $\mathrm{R}^{2}$ dapat dilihat pada Tabel 5 berikut ini:

\section{Tabel 5. Hasil Uji Koefisian Determinasi $\mathbf{R}^{2}$}

\begin{tabular}{|l|r|r|r|r|r|}
\hline \multicolumn{7}{|c|}{ Model Summary $^{\mathbf{b}}$} & \multicolumn{1}{c|}{$\begin{array}{c}\text { Adjusted R } \\
\text { Model }\end{array}$} & $\mathrm{R}$ & $\mathrm{R}$ Square & $\begin{array}{c}\text { Std. Error of the } \\
\text { Estimate }\end{array}$ & Durbin-Watson \\
\hline 1 & $.143^{\mathrm{a}}$ & .021 & -.011 & 3.923 & 1.550 \\
\hline
\end{tabular}
a. Predictors: (Constant), Promosi, Brand image, Perilaku Konsumen
b. Dependent Variable: Keputusan Pembelian 
Dari output di atas, terlihat nilai $\mathrm{R}$ square atau pengaruh simultan variabel Keputusan pembeliansebesar 0.414 . Selanjutnya, untuk mengukur besaran faktor luar pada Keputusan pembelian, digunakan rumus sebagai berikut:

$$
\begin{gathered}
\rho_{y} \varepsilon_{1}=\sqrt{1-\text { R Square }} \\
\rho_{y} \varepsilon_{1}=\sqrt{1-0.021} \\
=0.143
\end{gathered}
$$

Sehingga, dapat disimpulkan bahwa pengaruh perilaku konsumen juga turut mempengaruhi Keputusan pembelianadalah sebesar 0.143 $(14.3 \%)$

\section{Hasil Uji F}

Uji statistik $F$ adalah menunjukkan apakah variabel independen yang dimaksud dalam model mempunyai pengaruh secara bersama-sama terhadap variabel dependennya.Hasil pengujian statistik $\mathrm{F}$ dapat dilihat pada Tabel 6 berikut ini.

Tabel 6. Hasil Uji Statistik F

\begin{tabular}{|ll|r|r|r|r|r|}
\hline Model & & Sum of Squares & \multicolumn{1}{|c|}{ df } & Mean Square & \multicolumn{1}{c|}{ F } & Sig. \\
\hline 1 & Regression & 29.977 & 3 & 9.992 & .649 & $.585^{\mathrm{b}}$ \\
& Residual & 1430.931 & 93 & 15.386 & & \\
& Total & 1460.907 & 96 & & & \\
\hline
\end{tabular}

a. Dependent Variable: Keputusan Pembelian

b. Predictors: (Constant), Promosi, Brand image, Perilaku Konsumen

Berdasarkan Tabel 6 Terlihat nilai $\mathrm{F}$ hitung 0.649 dengan probabilitas 0,585 , itu berarti nilai probabilitas $<0,05$, sedangkan hasil yang diperoleh dari $\mathrm{F}$ tabel adalah sebesar 0.649 yang berarti $\mathrm{F}$ hitung $>\mathrm{F}$ tabel (0.649. $>0,287)$, sehingga model regresi dapat digunakan untuk memprediksi Keputusan pembeliankonsumen situs belanja online XYZ atau dapat disimpulkan bahwa Perilaku konsumen secara bersama-sama berpengaruh terhadap Keputusan pembelian konsumen situs XYZ, atau model sudah tepat.

\section{Hasil Uji Hipotesis (Uji Statistik t)}

Uji statistik $t$ pada dasarnya menunjukkan seberapa jauh pengaruh satu variabel penjelas/independen secara individual dalam menerangkan variasi variabel dependen. Pada uji t, nilai t hitungan dibandingkan dengan nilai $t$ tabel. Berikut hasil perhitungan uji statistik t yang disajikan

\begin{tabular}{|c|c|c|c|c|c|c|c|c|}
\hline \multirow{2}{*}{\multicolumn{2}{|c|}{ Model }} & \multicolumn{2}{|c|}{ Unstandardized Coefficients } & \multirow{2}{*}{$\begin{array}{c}\begin{array}{c}\text { Standardized } \\
\text { Coefficients }\end{array} \\
\text { Beta }\end{array}$} & \multirow[b]{2}{*}{$t$} & \multirow[b]{2}{*}{ Sig. } & \multicolumn{2}{|c|}{ Collinearity Statistics } \\
\hline & & $\mathrm{B}$ & Std. Error & & & & Tolerance & VIF \\
\hline 1 & (Constant) & 48.549 & 5.417 & & 8.963 & .000 & \multirow[b]{2}{*}{.593} & \multirow[b]{2}{*}{1.687} \\
\hline & $\begin{array}{l}\text { Perilaku } \\
\text { Konsumen }\end{array}$ & -.058 & .116 & -.067 & -.501 & .618 & & \\
\hline & Brand image & -.167 & .168 & -.121 & -.994 & .323 & .710 & 1.408 \\
\hline & Promosi & .043 & .145 & .040 & .300 & .765 & .588 & 1.701 \\
\hline
\end{tabular}
pada Tabel 7 sebagai berikut:

Tabel 7. Uji Statistik t

a. Dependent Variable: Keputusan Pembelian 
Berdasarkan hasil Uji t, maka pengambilan keputusannya berdasarkan Pengujian terhadap variable Keputusan Pembelianpada situs Belanja OnlineXYZ .Hipotesis pertama yang menyebutkan bahwa dimensi Perilaku Konsumen berpengaruh signifikan dan positif terhadap Keputusan Pembelian pada $X Y Z$ di terima. Berdasarkan hasil perhitungan data menggunakan program pengolahan data SPSS versi 24.0 diperoleh hasil bahwa nilai signifikansi sebesar 0.618 dengan arah hubungan positif. Ini berarti pengambilan keputusan terhadap hipotesis pertama adalah tolak $\mathrm{H} 0$ dan terima $\mathrm{H} 1$.

Hipotesis kedua yang menyebutkan bahwa dimensi Brand image berpengaruh signifikan dan positif terhadap keputusan pembelian pada situs belanja online $X Y Z$ diterima. Berdasarkan hasil perhitungan data menggunakan program pengolahan data SPSS versi 24.0 diperoleh hasil bahwa nilai signifikansi sebesar 0.323. Ini berarti pengambilan keputusan terhadap hipotesis kedua adalah terima $\mathrm{H} 2$ dan tolak $\mathrm{H} 0$ karena nilai signifikansi lebih besar dari 0,05 .

Hipotesis ketiga yang menyebutkan bahwa dimensi promosi berpengaruh signifikan dan positif terhadap Keputusan Pembelian pada situs belanja online $X Y Z$ diterima. Berdasarkan hasil perhitungan data menggunakan program pengolahan data SPSS versi 24.0 diperoleh hasil bahwa nilai signifikansi sebesar 0.765 . Ini berarti pengambilan keputusan terhadap hipotesis kedua adalah terima $\mathrm{H} 2$ dan tolak $\mathrm{H} 0$ karena nilai signifikansi lebih kecil dari 0,05.

\section{Kesimpulan}

\section{SIMPULAN DAN SARAN}

Berdasarkan hasil penelitian dan pembahasan, maka dapat diambil kesimpulan sebagai berikut : (1) Secara parsial, dimensi perilaku konsumen berpengaruh signifikan dan positif terhadap keputusan pembelian pada situs $E$ commerce $X Y Z$ ada di terima dengan nilai signifikansi sebesar 0.618, (2) Secara parsial, dimensi Brand image berpengaruh signifikan dan positif terhadap keputusan pembelian pada situs e-commerce $X Y Z$ diterima dengan nilai signifikansi sebesar 0.323 , (3) Secara parsial, dimensi promosi berpengaruh signifikan dan positif terhadap Keputusan Pembelian pada situs e-commerce diterima dengan nilai signifikansi sebesar 0.765 .

\section{Saran}

1. Variabel yang mempengaruhi keputusan pembelian konsumen dalam pembelian online pada situs e-commerce $X Y Z$ dalam penelitian ini terbatas pada empat variabel yaitu perilaku konsumen, brand image, promosi dan keputusan pembelian. Untuk penelitian selanjutnya dapat menggunakan variabel independen lain selain faktor-faktor tersebut.

2. Wilayah penelitian ini terbatas pada konsumen yang berada di wilayah Jakarta. Bagi peneliti lain dapat mengambil lokasi penelitian selain di Kota Jakarta.

3. Jumlah sampel yang digunakan dalam penelitian ini dibatasi hanya 97 responden. Bagi peneliti lain dapat menggunakan sampel lebih banyak lagi sehingga diperoleh hasil penelitian yang lebih akurat.

4. Perilaku konsumen mempunyai pengaruh paling besar terhadap keputusan pembelian konsumen situs e-commerce. Untuk itu jaminan kualitas hendaknya menjadi prioritas utama bagi perusahaan dan dijadikan komponen keunggulan/daya saing yang dimiliki perusahaan.

\section{DAFTAR PUSTAKA}

Aaker, D. A. (2007). "Managing Brand Equity". New York: Free Press

Ginting, Paham dan Syafrizal Helmi Situmorang, 2008. Filasafat Ilmu dan metode Riset, Usu Press, Medan

Dewanti, Retno.2008.Kewirausahaan. Jakarta: Mitra Wacana Media

Fandy Tjiptono, (2008). Brand Management And Strategy. Edisi Pertama. Andi, Yogyakarta

Fandy Tjiptono (2015). Pemasaran Strategik. Edisi Kelima. Andi, Yogyakarta

Ghozali, Imam. 2011. Aplikasi Analisis Multivariate Dengan Program IBM SPSS 19. Edisi Kelima. Semarang: Universitas Diponergoro

Hariri, Mahsa and HosseinVazifehdust. 2011. How Does Brand Extension Affect 
Brand Image?.International

Conference on Business and

Economics Research.Vol.1 . Kuala

Lumpur: IACSIT Press

Kunto, 2014, Analisa Pengaruh Brand Image

Dan Company Image Terhadap Loyalitas Retailer Studi Kasus Pt

Asia Paramita Indah. Jurnal

Manajemen Pemasaran Petra Vol. 2,

No. 1, (2014) 1-11.

Kotler, Philip. (2005). Marketing Management.11th Edition. Pearson Education Inc, NewJersey.

Kottler, Philip, Gary Amstrong. (2003)

Manajeman Pemasaran. Jilid

1.Jakarta : Ghalia Indonesia

Kotler, Philip dan Gary Armstrong.(2015).

Prinsip-prinsip Pemasaran.Jilid

2.Edisi 12. Erlangga, Jakarta

Sugiyono. 2012. Metode Penelitian

Kuantitatif Kualitatif dan $R \& D$.

Bandung: Alfabeta.

Sugiyono. 2015. Metode Penelitian Kuantitatif Kualitatif dan $R \& D$. Bandung: CV. Alfabeta

Suharismi Arikunto. Prosedur Penelitian Suatu Pendekatan Praktek.

Yogyakarta : BPFE Yogyakarta, 2010.

Suhari, Yohanes 2008, "Keputusan Membeli Secara Online dan Faktor-Faktor yang Mempengaruhinya", Jurnal Teknologi Informasi DINAMIK Volume XIII, No.2, Juli 2008 : 140146

https://id.wikipedia.org/wiki/LAZADA_Indo nesia 